\title{
ANALISIS TINGKAT KERUSAKAN WILAYAH PESISIR DI KABUPATEN MAMUJU TENGAH
}

\author{
Nurhikmah Paddiyatu \\ Dosen Prodi Arsitektur, Fakultas Teknik Universitas Muhammadiyah Makassar \\ nurhikmah@unismuh.ac.id
}

\begin{abstract}
ABSTRAK
Laju pertumbuhan penduduk dan pesatnya pembangunan di wilayah pesisir menyebabkan meningkatnya tekanan terhadap ekosistem pesisir. Ketidakmampuan mengelola secara berkelanjutan tersebut antara lain dipicu oleh kurang diperhatikannya prinsip-prinsip pembangunan terpadu dan berkelanjutan dalam kegiatan pemanfaatan sumberdaya pesisir. Dengan realita permasalahan pesisir yang demikian maka diperlukan analisis tingkat kerusakan wilayah pesisir sebagai langkah awal mewujudkan kelestarian dan keberlanjutan wilayah pesisir kabupaten Mamuju Tengah. Oleh karena itu, penelitian ini bertujuan untuk menentukan kawasan prioritas penanganan wilayah pesisir khususnya kawasan yang memiliki ekosistem mangrove serta sebagai referensi untuk program-program pengembangan wilayah pesisir kabupaten Mamuju Tengah. Selain itu, mengidentifikasi tingkat kerusakan wilayah pesisir Kabupaten Mamuju Tengah sebagai dasar dan referensi menentukan wilayah pesisir yang menjadi prioritas penanganan. Adapun metode analisis yang digunakan yaitu, analisis regression, analisis IPA (Importance Performance Analysis) serta analisis SWOT dimana dari analisis ini diperoleh strategi penanganan pada wilayah prioritas.
\end{abstract}

Kata Kunci: Mamuju Tengah, Tingkat Kerusakan, Wilayah Pesisir

\begin{abstract}
The rate growth of population and the rapidly developing in coastal areas has led to increasing pressure on coastal ecosystems. The inability to manage sustainably is triggered by the lack of attention to the principles of integrated and sustainable development in the activities of coastal resource utilization. With the reality of such coastal problems, it is necessary to analyze the level of damage to coastal areas as a first step to realize the conservation and sustainability of the coastal areas of Central Mamuju Regency. Therefore, this study aims to determine the priority areas of handling coastal areas, especially those that have mangrove ecosystems and as a reference for development programs in the coastal areas of Central Mamuju Regency. In addition, identifying the extent of damage to the coastal areas of Central Mamuju Regency as a basis and reference to determine the coastal areas that are the priority of treatment. The analytical methods used are regression analysis, IPA (Importance Performance Analysis) and SWOT analysis, which is from this analysis obtained strategies of handling in priority areas.
\end{abstract}

Keywords: Mamuju Tengah, Level of damage, Coastal areas

\section{PENDAHULUAN}

Indonesia merupakan negara kepulauan terbesar di dunia yang terdiri atas 13.466 pulau, dengan garis pantai sepanjang 81.000 $\mathrm{km}$. Luas laut Indonesia sekitar 3,1 juta $\mathrm{km}^{2}$ yang terdiri atas $0.8 \mathrm{~km}^{2}$ perairan teritorial, dan 2,3 juta $\mathrm{km}^{2}$ perairan nusantara. Dahuri et al. (1996) mendefinisikan wilayah pesisir sebagai suatu wilayah perairan antara daratan dan lautan dimana ke arah darat adalah jarak secara arbiter dan rata-rata pasang tertinggi dan batas ke arah laut adalah yurisdiksi wilayah propinsi atau state di suatu Negara. Kawasan pesisir merupakan wilayah peralihan antara daratan dan perairan laut. Secara fisiologi didefinisikan sebagai wilayah antara garis pantai hingga ke arah daratan yang masih dipengaruhi pasang surut air laut, dengan lebar yang ditentukan oleh kelandaian pantai dan dasar laut, serta dibentuk oleh endapan lempung hingga pasir yang bersifat lepas dan kadang materinya berupa kerikil. 
Wilayah pesisir dan laut Indonesia yang sangat luas tersebut mengandung sumberdaya yang potensial, sumberdaya hayati, nirhayati, dan dan jasa-jasa lingkungan. Namun, potensi tersebut belum dimanfaatkan secara optimal. Bahkan cenderung muncul gejala-gejala yang kurang baik, yaitu adanya cara-cara pemanfaatan yang membahayakan keberlanjutan pemanfaatan sumber daya pesisir.

Pengelolaan wilayah pesisir secara terpadu ditujukan agar kegiatan pemanfaatan sumberdaya alam dan jasa-jasa lingkungan pesisir dilakukan melalui penilaian secara menyeluruh, perencanaan tujuan dan sasaran, dan pengelolaan segenap kegiatan pemanfaatannya guna mencapai hasil pembangunan yang optimal dan berkelanjutan. Perencanaan dan pengelolaan wilayah pesisir dilakukan secara kontinyu dan dinamis dengan mempertimbangkan aspek ekologi, sosial ekonomi, kelembagaan, infrastruktur wilayah, dan aspirasi masyarakat pengguna wilayah pesisir, serta konflik kepentingan dan pemanfaatan yang mungkin ada.

Kompleksitas permasalahan wilayah pesisir tidak hanya menjadi tantangan daerah lain. Kabupaten Mamuju Tengah yang sebagian besar wilayahnya memiliki wilayah pesisir juga mengalami hal yang demikian. Wilayah pesisir yang dimaksud ini terdapat pada beberapa kecamatan diantaranya Budong-Budong, Pangale, Karossa dan Topoyo. Sebagai kabupaten yang memiliki wilayah pesisir yang cukup luas, keberadaan wilayah pesisir ini memiliki keanekaragaman hayati (ikan, terumbu karang, mangrove, dan biota laut lainnya), pasir, air laut, mineral, energi serta keindahan alam sebagai sumber mata pencaharian masyarakat dan potensi pariwisata yang tinggi. Kekayaan sumber daya alam pesisir Kabupaten Mamuju Tengah memicu aktivitas kegiatan manusia meningkat di wilayah ini sehingga terjadi eksplorasi dan eksploitasi besar-besaran yang berujung pada menurunnya kualitas lingkungan pesisir.

Keberadaan sumberdaya alam yang besar dan beragam di wilayah pesisir menyebabkan banyak instansi atau sektor pelaku pembangunan yang terlibat dalam pemanfaatan sumberdaya pesisir. Hal ini berakibat seringnya terjadi tumpang tindih pemanfaatan sumber daya alam antara satu sektor dengan sektor lainnya. Oleh karena itu perlu mengintegrasi semua kepentingan antar sektor agar dapat menghindari benturanbenturan antar kegiatan dalam pengembangan wilayah pesisir. Implementasi pengintegrasian antar sektor bisa dilakukan dengan perencanaan dan penataan ruang yang efektif, tepat sasaran dan komprehensif.

Mengingat begitu kompleks permasalahan wilayah pesisir, sifat, karakteristik, dan dinamika wilayah pesisir maka keberadaan Undang-Undang No.1 tahun 2014 tentang pengelolaan wilayah pesisir dan pulau-pulau kecil sangat strategis untuk mewujudkan keberlanjutan pengelolaan sumberdaya wilayah pesisir dan pulau-pulau kecil serta meningkatkan kesejahteraan masyarakat yang bermukim di wilayah pesisir. undang-undang ini mencakup pemberian hak kepada masyarakat untuk mengusulkan penyusunan Rencana Strategis, Rencana Zonasi, Rencana Pengelolaan, serta Rencana Aksi Pengelolaan Wilayah Pesisir dan Pulau-Pulau Kecil; pengaturan mengenai Izin Lokasi dan Izin Pengelolaan kepada Setiap Orang dan Masyarakat Hukum Adat, Masyarakat Lokal, dan Masyarakat Tradisional yang melakukan pemanfaatan sumber daya wilayah pesisir dan pulau-pulau kecil; pengaturan pemanfaatan pulau-pulau kecil dan perairan di sekitarnya; serta pemberian kewenangan kepada Menteri, gubernur, dan bupati/wali kota dalam Pengelolaan Wilayah Pesisir dan Pulau-Pulau Kecil.

Adapun lingkup wilayah pada analisis Tingkat Kerusakan Wilayah Pesisir di Kabupaten Mamuju Tengah berada pada kecamatan yang berbatasan langsung dengan wilayah pesisir yaitu, Kecamatan BudongBudong (Desa Babana, Kire, dan Lumu), Kecamatan Topoyo (Desa Budongbudong/Patulana, Tumbu), Kecamatan Karossa (Desa Karossa dan Kambunong) serta Kecamatan Pangale (Desa Kombiling, dan Lamba-lamba). 


\section{METODE PENELITIAN}

Metode pendekatan yang digunakan dalam pelaksanaan penelitian ini yaitu pendekatan spasial, pendekatan komunitas/masyarakat (Community Approach) serta pendekatan Komprehensif.

Selain itu, Untuk memudahkan penelitian, akan digunakan penentuan sampel dalam pengambilan data dari unit yang akan dianalisis. Sampel itu sendiri, merupakan sebagian anggota dari populasi yang pemilihannya menggunakan prosedur tertentu, sehingga diharapkan sampel yang terpilih tersebut dapar merepresentasikan kondisi populasinya (Sugiharto, et.al, 2003). Sampel yang digunakan dalam penelitian ini yaitu penduduk yang berada pada wilayah kecamatan di Kabupaten Mamuju Tengah yang berbatasan langsung dengan wilayah pesisir.

Terdapat empat kecamatan dari lima kecamatan pada wilayah Kabupaten Mamuju Tengah yang menjadi objek penelitian, karena salah satu wilayah kecamatan yaitu Kecamatan Tobadak, tidak memenuhi kriteria sebagai wilayah penelitian karena tidak memiliki wilayah pesisir. Teknik pengambilan sampel pada penelitian ini yaitu menggunakan metode acak (random sampling). Adapun metode analisis yang digunakan yaitu, analisis regression, analisis IPA serta analisis SWOT.

Pada analisis yang digunakan untuk menguji faktor-faktor yang berpengaruh terhadap tingkat kerusakan adalah analisis regresi linier berganda. Regresi linier berganda merupakan suatu metode analisis statistik yang mempelajari pola hubungan antara dua atau lebih variabel (Soleh, 2005). Menurut Ridwan (2005) skala Likert digunakan untuk mengukur sikap, pendapat dan persepsi seseorang atau kelompok tentang kejadian atau gejala sosial. Kriteria atau indikator yang digunakan untuk mengetahui tingkat kerusakan mangrove di wilayah peisisr Kabupaten Mamuju Tengah yaitu, sebagai berikut :

\section{Tabel 1. Kriteria Interpretasi Skor}

\begin{tabular}{l|l} 
Indikator & Tingkat kerusakan \\
\hline
\end{tabular}

\begin{tabular}{c|c}
\hline Indikator & Tingkat kerusakan \\
\hline $0 \%-9 \%$ & Sangat Baik \\
\hline $20 \%-39 \%$ & Baik \\
\hline $40 \%-59 \%$ & Sedang \\
\hline $60 \%-79 \%$ & Rusak \\
\hline$\geq 80 \%$ & Sangat rusak \\
\hline
\end{tabular}

Importance performance analysis (IPA) merupakan sebuah analisis yang diperkenalkan oleh Martilla dan James (1997) sebagai suatu alat untuk mengidentifikasi fasilitas maupun lokasi yang membutuhkan penanganan prioritas berdasarkan performa dari setiap lokasi dan bobot tingkat kepenting an pada setiap lokasi.

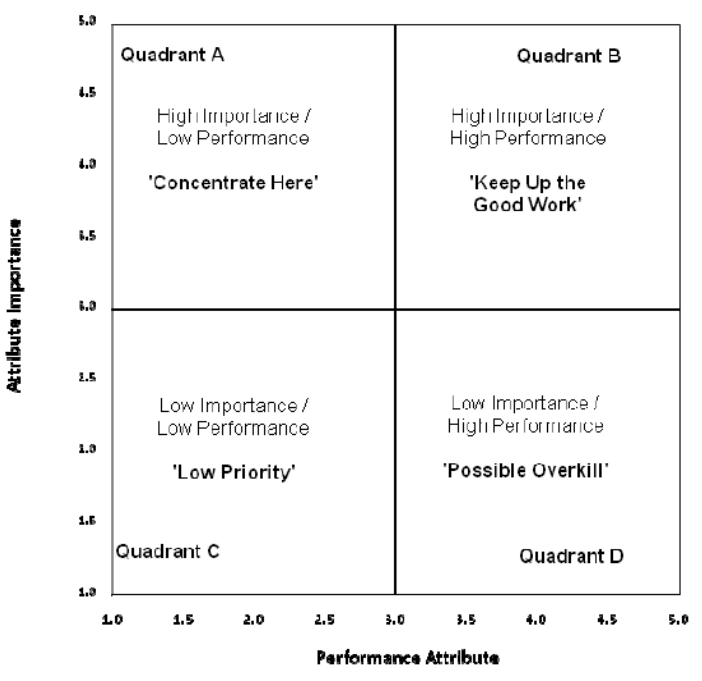

Gambar 1. Diagram Kartesius Analisis IPA

Analisis ini terdiri dari dua komponen analisis, yaitu performa yang diwakili oleh nilai masing-masing indikator yang ditentukan dari setiap kecamatan, yaitu performa yang diwakili oleh nilai fasilitas dan jenis kerusakan pada setiap kecamatan, serta tingkat prioritas yang diwakili oleh bobot dari setiap kecamatan yang dilihat dari kedudukan dan fungsi kecamatan. Nilai kedua variabel ini kemudian diplot ke dalam sebuah diagram kartesius dengan dua sumbu utama, yaitu sumbu $x$ dan sumbu $y$. Nilai performansi setiap kecamatan berada pada sumbu $x$, dan nilai tingkat pembobotan atau prioritas kecamatan berada pada sumbu y. Area yang ada pada antara dua sumbu ini kemudian dibagi menjadi 4 (empat) kuadran, 
dimana garis pembagi ini didasarkan pada nilai batas bawah atau minimum. Setelah menentukan nantinya nilai batas bawah yang menjadi garis pembagi pada diagram IPA ini, maka nantinya akan dihasilkan empat kuadran yang menentukan perfoma dan tingkat prioritas pada setiap kecamatan yang telah dibobotkan. Dimana empat kuadran, dapat dilihat secara jelas pada ilustrasi diagram (gambar 1 ):

Kuadran I, pada bagian ini nantinya akan menunjukkan lokasi yang memiliki nilai tingkat kepentingan yang tinggi, namun memiliki nilai performa lokasi yang rendah; Kuadran II, pada bagian ini nantinya akan menunjukkan lokasi yang memiliki nilai tingkat kepentingan dan perfoma yang sama-sama tinggi; Kuadran III, pada bagian ini nantinya akan menunjukkan lokasi yang memiliki nilai tingkat kepentingan dan performa yang rendah; Kuadran IV, pada bagian ini nantinya akan menunjukkan lokasi yang memiliki nilai tingkat kepentingan rendah, namun memiliki nilai perfoma lokasi yang tinggi. Hasil dari setiap kuadran ini nantinya, merupakan acuan dalam penelitian ini yang nantinya akan dijadikan sebagai patokan dalam menentukan perfoma apa saja yang harus ditangani lebih dahulu serta wilayah mana yang menjadi lokasi prioritas penangan.

Analisis SWOT adalah analisis untuk mengetahui faktor-faktor yang mempengaruhi kondisi kawasan pesisir di lokasi penelitian, yaitu untuk melihat strength (kekuatan), weakness (kelemahan), opportunity (kesempatan) dan threath (ancaman), serta menginventarisasi faktor-faktor tersebut dalam strategi arahan penanganan kerusakan kawasan pesisir yang ideal. Faktor-faktor yang mempengaruhi dalam konsep penanganan tersebut adalah sebagai berikut:

Potensi (strength): kekuatan apa yang dapat dikembangkan dan dimiliki oleh lokasi penelitian dalam menunjang pengembangan kawasan pesisir.

Masalah (weakness) : segala faktor yang merupakan masalah atau kendala yang datang dari dalam wilayah atau obyek itu sendiri

Peluang (opportunities): Kesempatan yang berasal dari luar wilayah studi. Kesempatan tersebut diberikan sebagai akibat dari pemerintah, peraturan atau kondisi ekonomi secara global

Ancaman (threat): merupakan hal yang dapat mendatangkan kerugian yang berasal dari luar wilayah atau obyek.

\section{HASIL DAN PEMBAHASAN}

Wilayah pesisir dalam penelitian ini mencakup dalam empat kecamatan, yaitu kecamatan Topoyo, Kecamatan BudongBudong, Kecamatan Pangale, dan Kecamatan Karossa. Lokasi penelitian pada analisis tingkat kerusakan wilayah Pesisir di Kabupaten Mamuju Tengah berada pada kecamatan yang berbatasan langsung dengan wilayah pesisir yaitu, Kecamatan Budong-Budong (Desa Babana, Kire, dan Lumu), Kecamatan Topoyo (Desa Budong-budong/Patulana, Tumbu), Kecamatan Karossa (Desa Karossa dan Kambunong) serta Kecamatan Pangale (Desa Kombiling, dan Lamba-lamba) dapat dilihat pada (gambar 2).

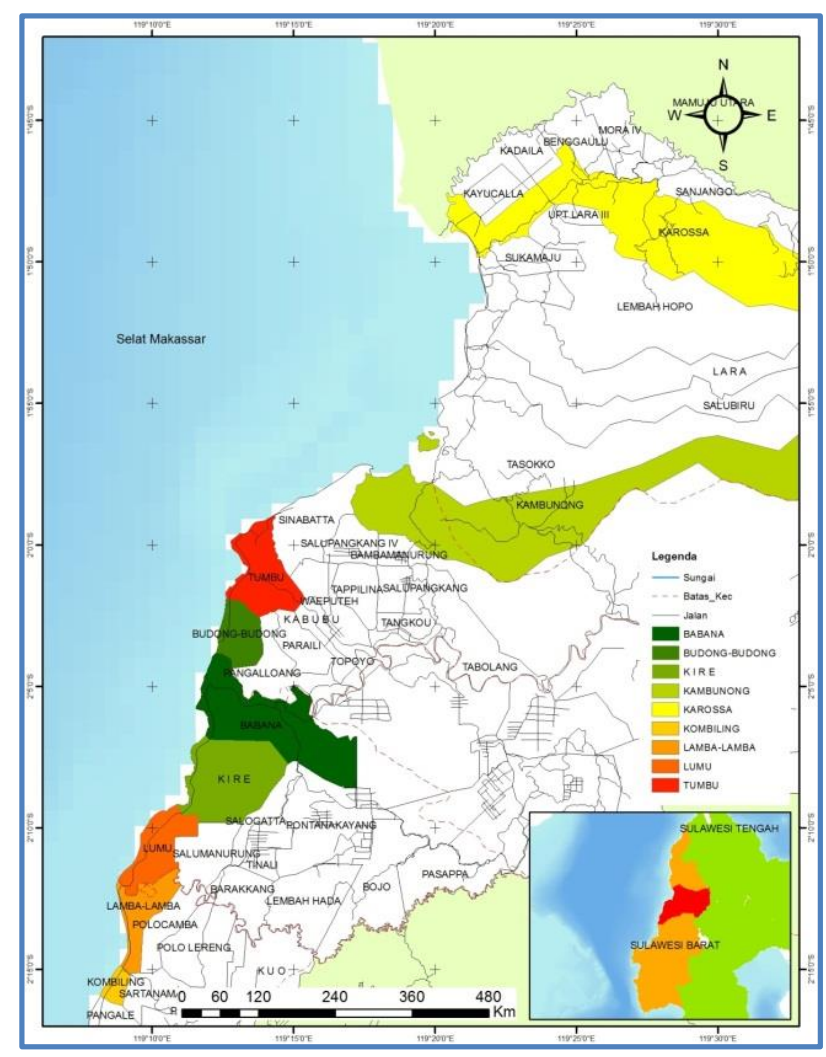

Sumber : Hasil Olahan Peta RTRW Mamuju Tengah, 2017 
Gambar 2. Orientasi Kecamatan pada Lokasi Penelitian

\section{Kondisi Wilayah Pesisir}

Mamuju Tengah memiliki kawasan pesisir dengan tingkat kelandaian rendah $(<3 \%)$ dengan kedalaman kurang dari $10 \mathrm{~m}$ berkisar antara $1,91-32,86 \%$. Selain itu, Kedalaman pesisir $<10 \mathrm{~m}$ sedimen dengan struktur terdiri dari pasir halus - lumpur berpasir.

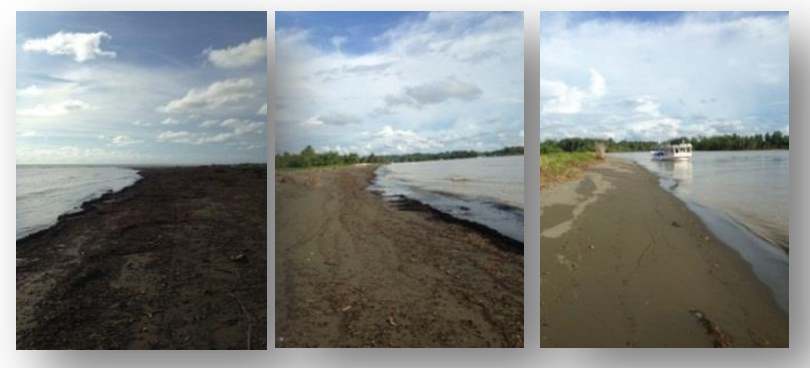

Sumber : Dokumentasi Penulis, 2017

Gambar 3. Kondisi Perairan Pesisir di Desa Budong-Budong yang telah dipengaruhi oleh massa air sungai

Limbah pengolahan kelapa sawit atau limbah industri kelapa sawit merupakan salah satu pencemar di wilayah pesisir Kabupaten Mamuju Tengah. Tidak tersedianya prasarana persampahan menjadikan masyarakat membuang sampah di sekitar perairan laut atau membakarnya.

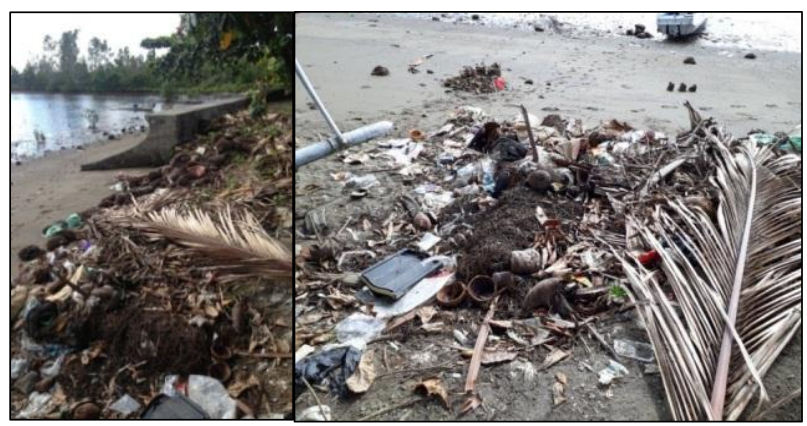

Sumber : Dokumentasi Penulis, 2017

Gambar 4. Kondisi Buangan Limbah Padat di Desa Tumbu
Selain itu, pada limbah cair di kawasan pesisir kabupaten Mamuju Tengah memperlihatkan kadar phosphat khususnya di perairan laut Mamuju Tengah. Pada perairan dekat pemukiman pesisir kadar phosphat cukup tinggi bersumber dari limbah deterjen. Kadar phosphat pada umumnya telah melebihi 0,015 $\mathrm{mg} / \mathrm{L}$.

Disamping itu, selain terjadi kerusakan fisik perairan, juga terjadi kerusakan biotik atau vegetasi di sepanjang wilayah pesisir dalam hal ini di desa Lamba-Lamba Kecamatan Pangale. Tumbangnya vegetasi di sekitar pantai berupa kelapa, pohon capilong atau nyamplung (Calophyllum inophyllum) di sepanjang pesisir Kecamatan Pangale yang disebabkan oleh gelombang yang yang menghantam wilayah pesisir secara terus menerus. Serta tertutupnya padang lamun oleh batu karang yang dibawa oleh gelombang dari wilayah empasan (gambar 5). Dampak abrasi juga berpengaruh pada tanggul yang berada di desa Lamba-Lamba sebagai penahan ombak.

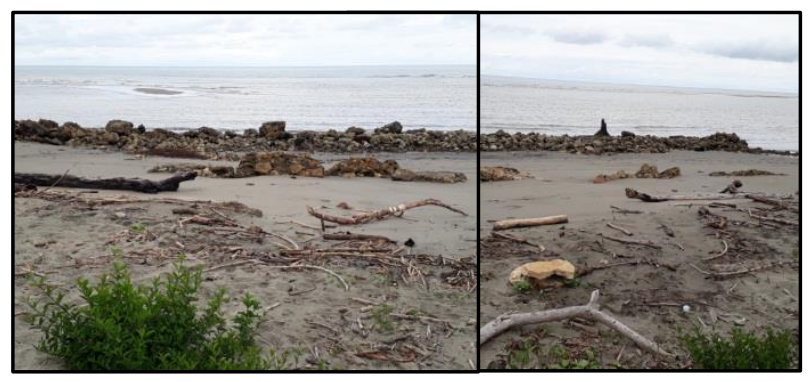

Sumber : Dokumentasi Penulis, 2017

Gambar 5. Tanggul sepanjang \pm 30 meter di desa Lamba-lamba yang Runtuh Akibat Hantaman Ombak

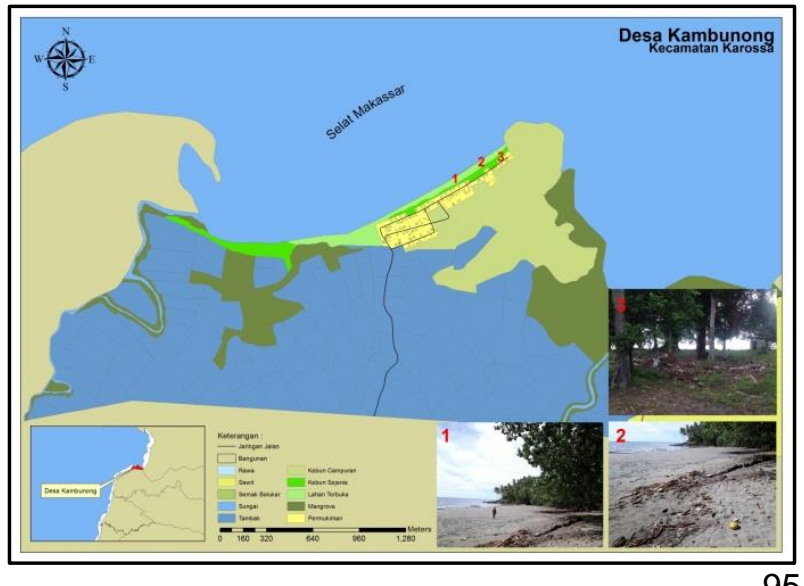


Gambar 6. Kondisi Prasarana jaringan jalan di Lokasi Penelitian

Terdapat beberapa kawasan pesisir yang masih memiliki infrastruktur belum memadai. Infrastrukur tersebut yaitu seperti jaringan jalan (gambar 6), drainase, tempat sampah, serta listrik.

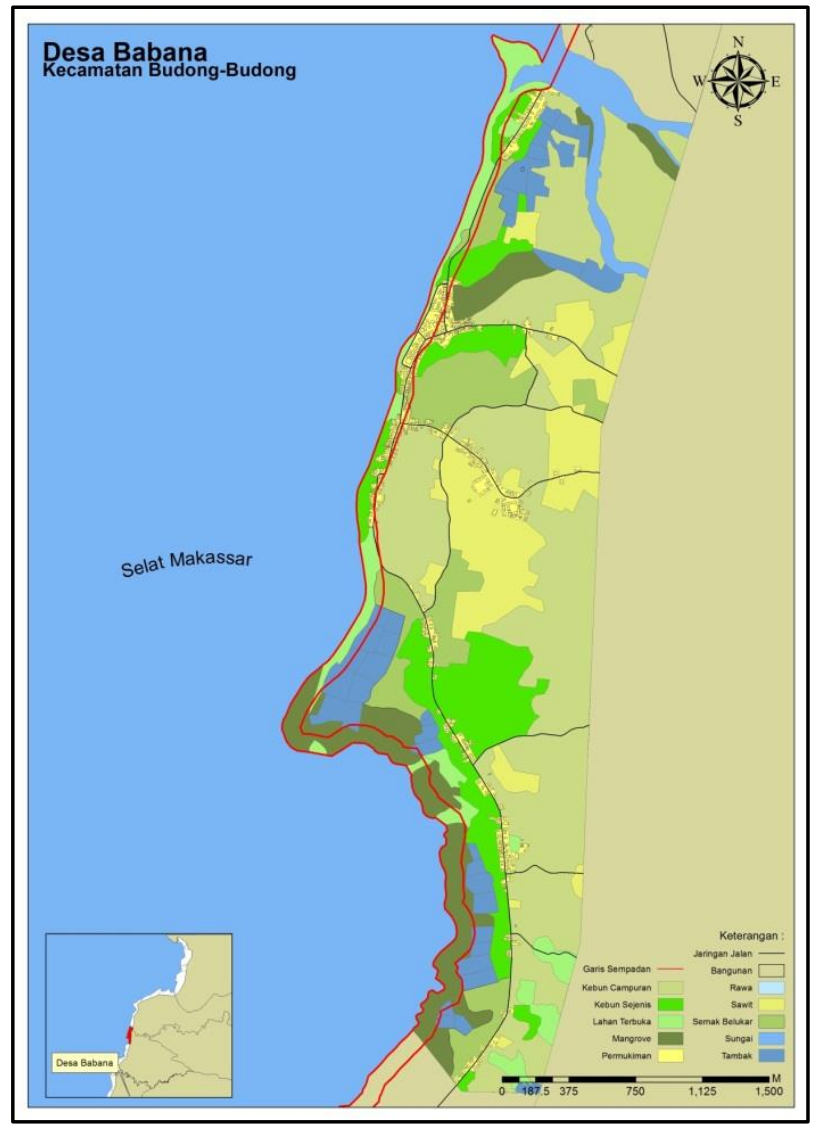

Sumber: Hasil Digitasi, 2017

Gambar 7. Kondisi Sempadan Pantai di Sepanjang Pesisir Desa Babana

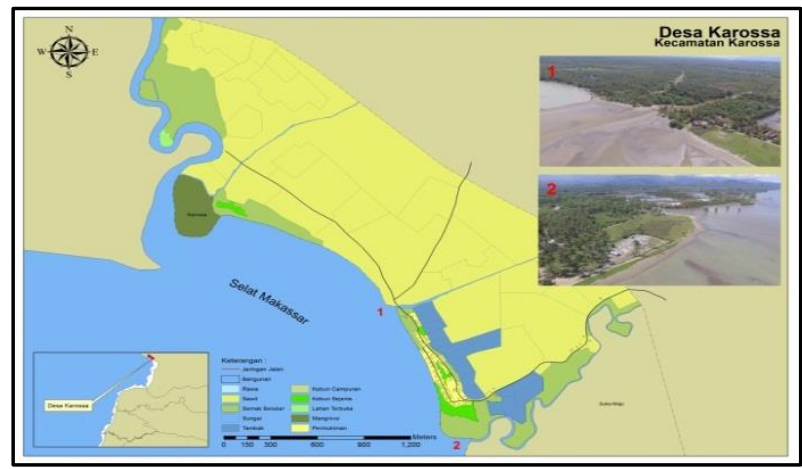

Gambar 8. Sedimentasi di Muara Sungai BudongBudong

Garis Sempadan Pantai (GSP) merupakan batas wilayah pantai atau wilayah pesisir yang tidak boleh dimanfaatkan untuk lahan budidaya maupun untuk didirikan bangunan. Dapat dilihat garis sempadan yang ditarik 100 (seratus) meter dari titik pasang tertinggi ke arah darat. Pada lokasi penelitian, masih terdapat beberapa lahan tambak dan bangunan yang berada di sepanjang kawasan pesisir dengan luasan 228,16 ha (gambar 7).

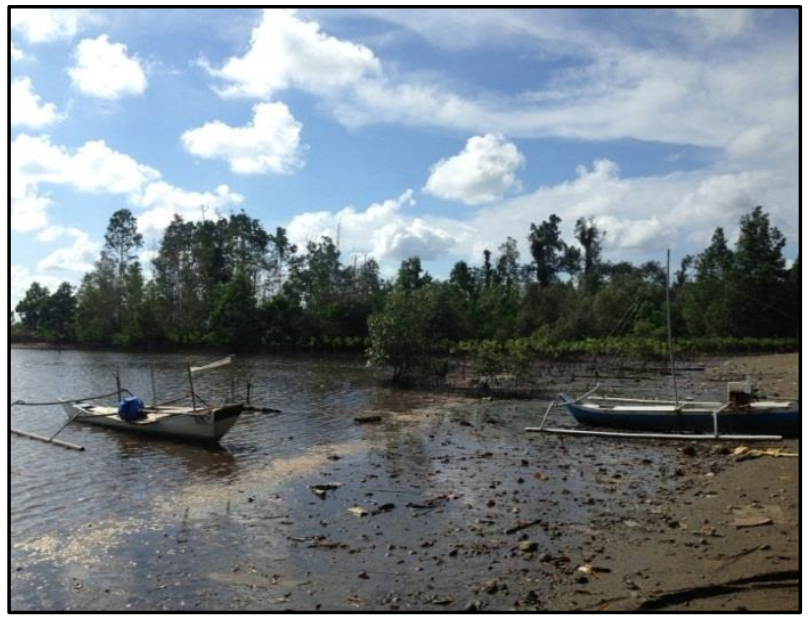

Sumber : Dokumentasi Penulis, 2017

Gambar 9. Kondisi Ekosistem Mangrove di Desa Tumbu' Kecamatan Tapoyo

Berdasarkan data dokumen laporan akhir RZWP3K Provinsi Sulawesi Barat Tahun 2016, terdapat sampling pada tiga kecamatan yaitu Kecamatan Budong-Budong, Topoyo dan Karossa, sedangkan pada Kecamatan Pangale tidak dilakukan sampling

Pada tiga kecamatan tersebut ditemukan 6 jenis yaitu Rhizophora mucronata, $R$. apiculata, Avicennia officinalis, Sonneratia alba, S. ovata dan Bruguiera gymnorrhiza.

Kecamatan Budong-Budong mempunyai dua jenis, sedangkan Kecamatan Topoyo dan Karossa masing-masing mempunyai 3 jenis. Kepadatan mangrove yang didapatkan bekisar 867-1567 pohon/ha, dimana kepadatan tertinggi ditemukan di 
Kecamatan Karossa (Pulau Kambuno). Jenis Sonneratia alba mempunyai kepadatan tertinggi di Kecamatan Budong-Budong dan Topoyo, masing-masing sebesar 700 pohon/ha dan 733 pohon/ha, sedangkan di Kecamatan Karossa ketiga jenis mangrove mempunyai kepadatan yang relatif sama.

\section{Analisis Regression}

Pada analisis ini, variabel bebas atau independent yang diperoleh merupakan faktorfaktor yang berpengaruh pada tingkat kerusakan mangrove. Adapun beberapa variabel yang dimaksud yaitu (1) intensitas Pengamanan, (2) penebangan Kayu Bakau, (3) kegiatan pertambakan, (4) kegiatan perkebunan dan pertanian, (5) pemanfaatan hasil hutan non kayu, (6) intensitas penyuluhan atau sosialisasi, (7) kedekatan dengan industri pengolahan kayu bakau, (8) keberadaan kelompok swadaya masyarakat, keberadaan lembaga swadaya masyarakat, dan (10) tingkat pemahaman masyarakat terhadap lingkungan.

Dasar analisis meninjau pada hasil survey dalam observasi serta interview dengan masyarakat setempat. Hasil tersebut diinput dalam program SPSS yang kemudian diolah menggunakan analisis regresi linier berganda. Keseluruhan variabel dianalisis pada 4 item regression yaitu; (1) descriptive Statistic, (2) correlations (3) variable entered, (4) annova (5) Model Summary, (6) Coefficients, (7) diagram. Dimana dari hasil output SPSS, item correlations dan coefficients ini dapat diketahui bahwa variabel tingkat kerusakan ekosistem mangrove dipengaruhi oleh kegiatan dari penebangan kayu bakau dan memiliki hubungan yang cukup kuat yaitu sebesar $73 \%$. Variabel dependen tingkat kerusakan ekosistem mangrove dipengaruhi oleh variabel predictor yaitu variabel penebangan kayu bakau (dari 10 variabel yang dimasukkan) bahwa semakin tinggi nilai variabel penebangan kayu bakau semakin tinggi pula tingkat kerusakan ekosistem mangrove di kawasan pesisir kabupaten Mamuju Tengah. Sebaliknya, jika nilai variabel penebangan kayu bakau semakin berkurang, maka jumlah tingkat kerusakan ekosistem mangrove juga akan ikut menurun. Setiap penambahan $1 \%$ kegiatan penebangan kayu bakau akan meningkatkan tingkat kerusakan ekosistem mangrove sebesar $0,711 \%$.

Analisis pada penilaian tingkat kerusakan ini disesuaikan pula dengan kondisi kerapatan Mangrove dari hasil penelitian (RZWP3K) pada tahun sebelumnya.

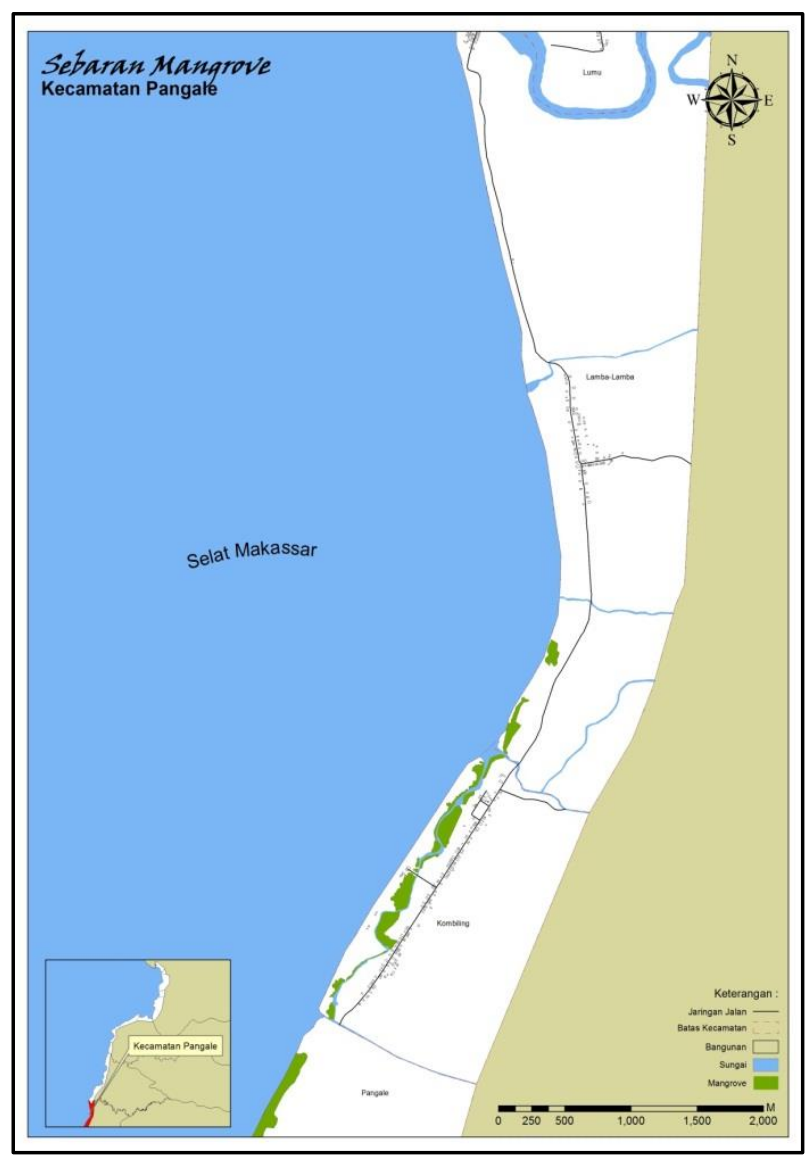

Gambar 10. Persebaran tutupan Lahan Mangrove di Kecamatan Pangale

\section{Tabel 2. Tingkat Ekosistem Kerusakan Mangrove (Yi)}

\begin{tabular}{|c|c|c|c|c|}
\hline Nilai & $\begin{array}{l}\text { Tingkat } \\
\text { Kerusakan }\end{array}$ & Indikator & Frekuensi & $\begin{array}{c}\text { Proporsi } \\
(\%)\end{array}$ \\
\hline 1 & $\begin{array}{l}\text { Sangat } \\
\text { Baik }\end{array}$ & $0-19 \%$ & - & - \\
\hline 2 & Baik & $20-39 \%$ & 4 & 14 \\
\hline 3 & Sedang & $40-59 \%$ & 11 & 40 \\
\hline 4 & Rusak & $60-79 \%$ & 13 & 46 \\
\hline 5 & $\begin{array}{l}\text { Sangat } \\
\text { Rusak }\end{array}$ & $\geq 80 \%$ & - & - \\
\hline
\end{tabular}




\begin{tabular}{|c|c|c|c|c|}
\hline Nilai & $\begin{array}{c}\text { Tingkat } \\
\text { Kerusakan }\end{array}$ & Indikator & Frekuensi & $\begin{array}{c}\text { Proporsi } \\
(\%)\end{array}$ \\
\hline & Jumlah & & 28 & 100 \\
\hline
\end{tabular}

Sumber: Hasil Analisis, 2017

Dalam konteks ini diperoleh jumlah atau frekuensi yang ditinjau berdasarkan kriteria baku kerusakan mangrove (tabel 2) serta gambaran kondisi eksisting mangrove di lapangan. Terdapat dengan jumlah frekuensi 28 titik (kawasan) dari keseluruhan tutupan lahan ekosistem mangrove yang berlokasi di sepanjang wilayah pesisir kabupaten Mamuju Tengah.

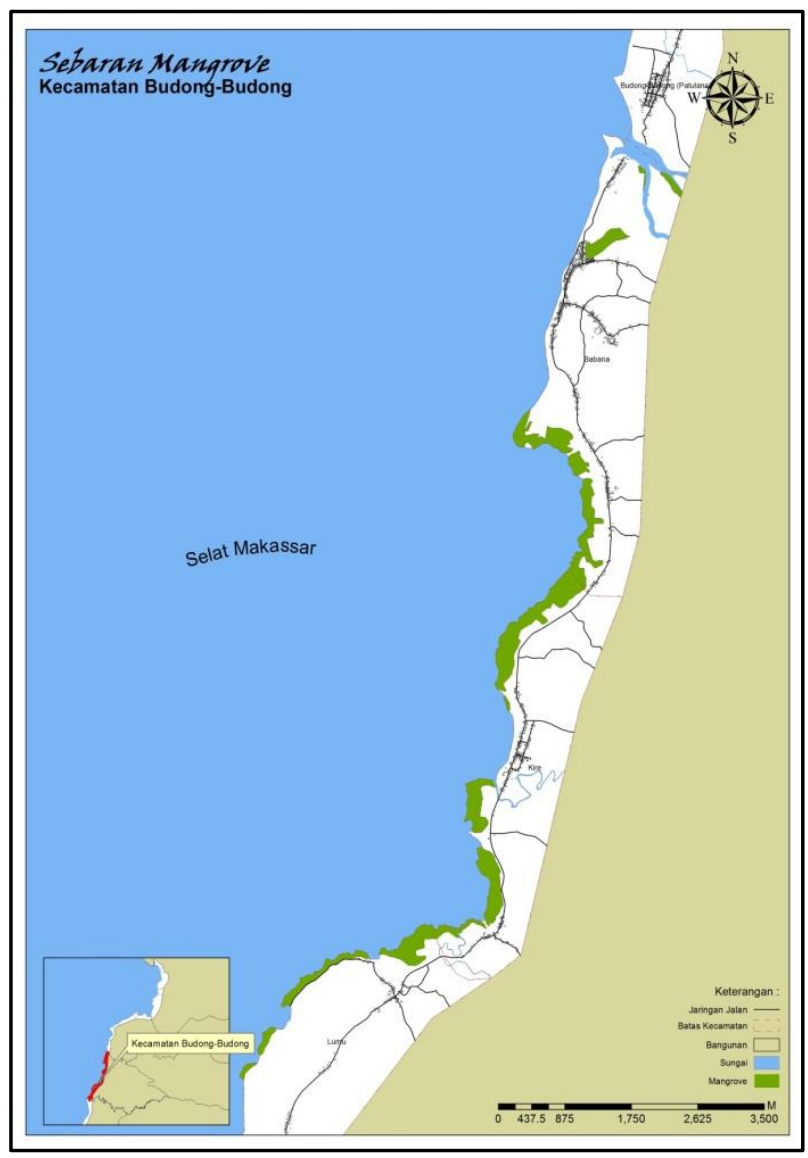

Gambar 11. Persebaran Tutupan Lahan Mangrove di Kecamatan Budong-budong

Dari hasil penilaian tabel di atas, menunjukkan bahwa klasifikasi pada tingkat 'rusak' tutupan lahan ekosistem mangrove memiliki proporsi $46 \%$ berada dominan pada kawasan pesisir di kecamatan Pangale dan kecamatan budongbudong (gambar 10, gambar 11).

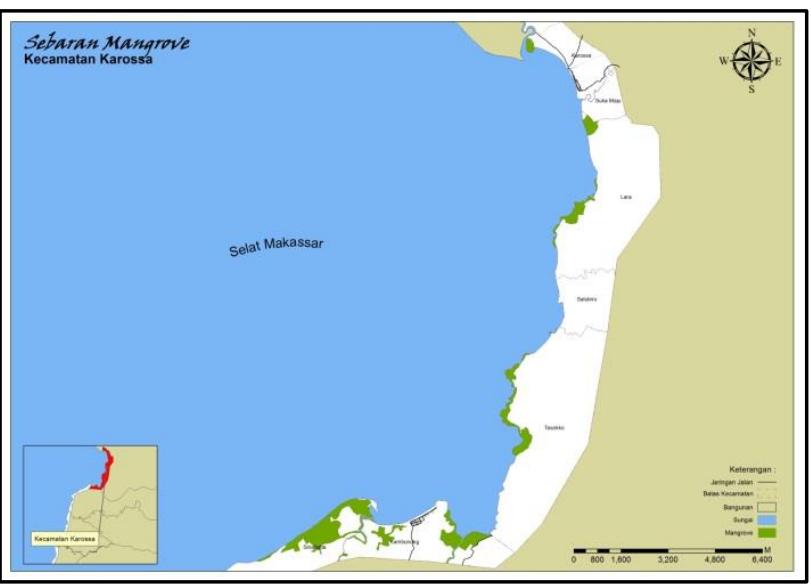

Gambar 12. Persebaran Tutupan Lahan Mangrove di Kecamatan Karossa

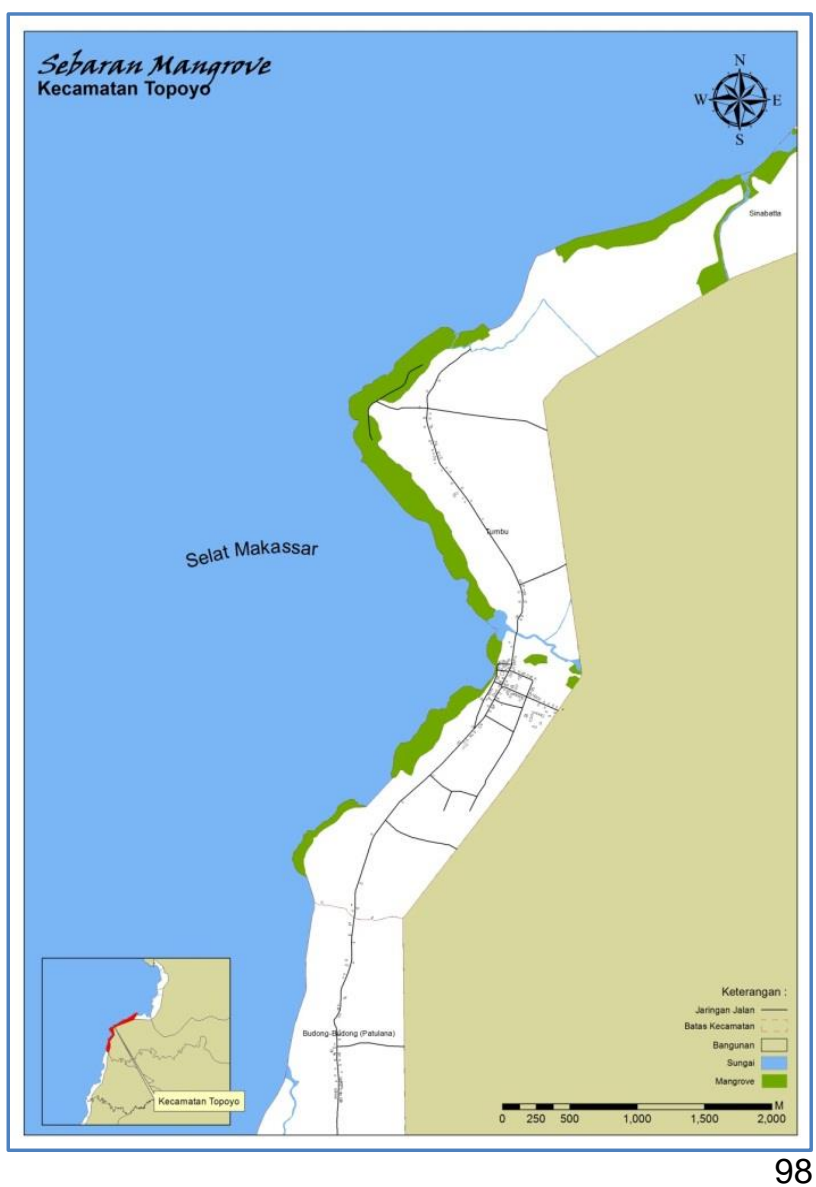


Gambar 13. Persebaran Tutupan Lahan Mangrove di Kecamatan Topoyo

\section{Analisis IPA}

Dari hasil perhitungan tingkat kesesuaian total untuk indikator kinerja $(X)$ dan harapan $(Y)$ diperoleh sebesar 68\%. Hal tersebut mengindikasikan bahwa nilai performansi dari setiap indikator yang menjadi tolak ukur dari responden masih sangat perlu ditingkatkan, karena nilai ini masih sangat jauh untuk mencapai harapan yang diinginkan oleh responden baik itu dalam hal kerusakan yang terjadi serta ketersediaan sarana dan prasarana pendukung yang ada pada setiap kecamatan di Kabupaten Mamuju Tengah yang berbatasan langsung dengan wilayah pesisir. Terlihat pula pada hasil diagram cartesius, dimana dari setiap kuadran yang ada, akan menunjukkan tingkat prioritas untuk setiap indikator atau variabel yang telah dinilai.

Sehingga, hasil dari diagram kartesius dilihat dari kuadrannya (gambar 14), maka variabel penilaian yang perlu mendapatkan penanganan prioritas berada pada kuadran $A$ yaitu variabel 1,2,3,7,15,21 dan 29. Kemudian dari 7 variabel yang berada pada kuadran $A$, akan dipilih variabel yang memiliki nilai ratarata yang paling rendah.
Berdasarkan pada nilai-nilai yang dihasilkan dari analisis IPA, maka analisis scoring dapat dilakukan dengan tujuan untuk mengetahui wilayah pesisir mana yang berada

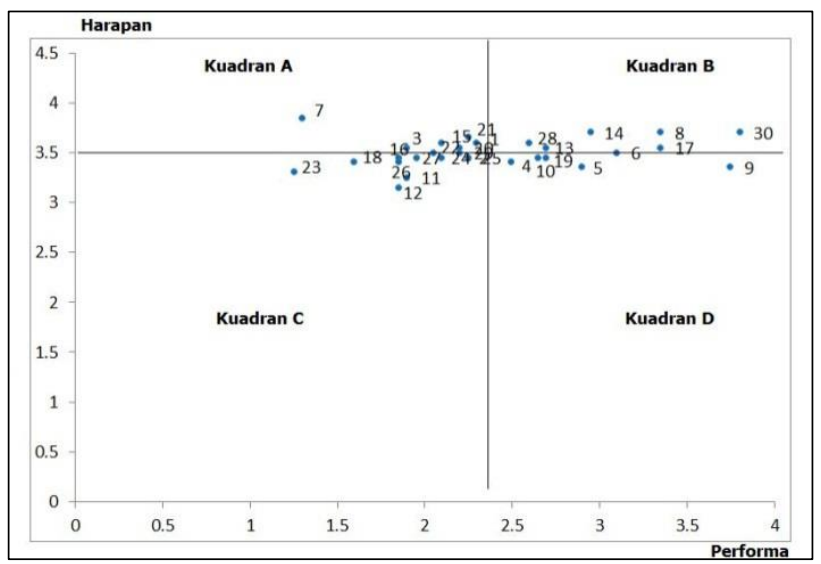

Sumber : Hasil Analisis, 2017

Gambar 14. Diagram Kartesius

pada wilayah penelitian dan memiliki skor terendah dan tertinggi, yang mana skor terendah inilah yang akan menjadi dasar nantinya dalam penetapan lokasi penanganan prioritas pada Kabupaten Mamuju Tengah yang berbatasan langsung dengan wilayah pesisir. Olahan data scoring diperoleh dari hasil kuesioner (penilaian masyarakat pesisir) serta menunjukkan persepsi masyarakat pesisir.

Tabel 5. Skoring Indikator Lokasi Wilayah Penelitian

\begin{tabular}{|c|c|c|c|c|c|c|c|}
\hline \multirow[b]{2}{*}{ No } & \multirow[b]{2}{*}{$\begin{array}{l}\text { Lokasi } \\
\text { (Kec.) }\end{array}$} & \multicolumn{5}{|c|}{ Nilai Indikator (X1-X30) } & \multirow[b]{2}{*}{$\begin{array}{l}\text { Skor } \\
\text { Total }\end{array}$} \\
\hline & & $\begin{array}{l}\text { Kondisi } \\
\text { wilayah } \\
\text { pesisir }\end{array}$ & $\begin{array}{c}\text { Perilaku } \\
\text { terhadap } \\
\text { wilayah } \\
\text { pesisir }\end{array}$ & $\begin{array}{c}\text { Peran } \\
\text { pemerintah } \\
\text { terhadap } \\
\text { wilayah } \\
\text { pesisir }\end{array}$ & $\begin{array}{c}\text { Penyebab } \\
\text { kerusakan } \\
\text { wilayah } \\
\text { pesisir }\end{array}$ & $\begin{array}{c}\text { Kondisi } \\
\text { infrastruktur }\end{array}$ & \\
\hline 1 & Topoyo & 26 & 52 & 37 & 51 & 55 & 221 \\
\hline 2 & Pangale & 24 & 52 & 30 & 60 & 52 & 218 \\
\hline 3 & $\begin{array}{l}\text { Budong- } \\
\text { Budong }\end{array}$ & 28 & 49 & 39 & 50 & 58 & 224 \\
\hline 4 & Karossa & 26 & 54 & 39 & 70 & 48 & 237 \\
\hline
\end{tabular}

Sumber : Hasil Analisis, 2017 
Berdasarkan pada hasil skoring diatas, diketahui bahwa pada Kabupaten Mamuju Tengah, wilayah pesisir yang memiliki nilai paling tinggi adalah Kecamatan Karossa dan yang memiliki nilai paling rendah adalah Kecamatan Pangale. Sehingga dari hasil ini dapat disimpulkan bahwa untuk kabupaten Mamuju Tengah wilayah yang memerlukan penanganan prioritas adalah Kecamatan Pangale, karena nilai totalnya yang lebih rendah dibandingkan dengan kecamatan lain pada lokasi penelitian.

\section{Analisis SWOT}

Analisis SWOT bertujuan untuk ikut melakukan konsep strategi penanganan dalam kerusakan kawasan pesisir ditinjau dari aspek kebijakan dan tindakan langsung di lapangan. Analisis SWOT adalah analisis untuk mengetahui faktor-faktor yang mempengaruhi kondisi kawasan pesisir di lokasi penelitian, yaitu untuk melihat Strength (kekuatan), Weakness (kelemahan), Opportunity (kesempatan) dan Threath (ancaman), serta menginventarisasi faktor-faktor tersebut dalam strategi arahan penanganan kerusakan kawasan pesisir yang ideal.

\section{Kekuatan Strengths (S)}

Wilayah pesisir Kabupaten Mamuju tengah memilki potensi yang sangat beragam diantaranya adalah wisata bentang alam di perairan Kecamatan Pangale, Budong-budong dan topoyo, sebagai tempat budidaya laut di Kecamatan Karossa, dan areal potensi penangkapan ikan demersal yang berada di Kecamatan Pangale, Budong-budong, Topoyo dan Karossa.

\section{Kelemahan/Weaknesses (W)}

Sedimentasi perairan yang berada di muara sungai dan terjadinya pergeseran garis pantai sehingga berubahnya daratan menjadi laut; Sistem keamanan di kawasan pesisir dan laut, yang masih belum optimal; Masih terdapat pencemaran yang bersumber dari aktifitas daratan, seperti buangan limbah padat dari aktifitas masyarakat setempat (kawasan pesisir). Pengelolaan sumberdaya alam khususnya sektor pertanian, perkebunan, perikanan, peternakan dan kehutanan belum dikelola secara maksimal.

\section{Peluang/Opportunity (0)}

Beberapa peluang diantaranya adalah Kegiatan perekonomian masyarakat pesisir dalam usaha pertanian dan perkebunan (misalnya usaha kopra); dan Kawasan pesisir yang bebas dari aktifitas pencemaran limbah padat dan cair, serta memiliki lingkungan pesisir yang sehat dan bersih dapat meningkatkan keanekaragaman ekosistem pesisir.

\section{Ancaman/Threats (T)}

Sempadan pantai yang seharusnya menjadi kawasan konservasi mulai beralih fungsi. Dimana awalnya didominasi oleh mangrove berubah menjadi kawasan permukiman, pertanian/ lahan tambak. Perubahan demikian bisa jadi ancaman di masa yang akan datang berupa degradasi lingkungan dan potensi bencana. Sebagai contoh penyusutan mangrove akan kehilangan fungsinya sebagai tanaman penahan gelombang dan merupakan habitat beberapa makhluk perairan.

Adapun strategi penanganan yang diperoleh dari hasil analisis SWOT menggunakan pendekatan sustainable development. Konsep sustainable development/ pembangunan berkelanjutan memiliki tiga pilar utama yang digunakan sebagai strategi dalam pengelolaan wilayah pesisir. Tiga pilar tersebut adalah pembangunan sosial, ekonomi dan lingkungan. Diharapkan dengan strategi demikian dapat meminimalisir dan mencegah terjadi kerusakan wilayah pesisir yang lebih kompleks.

Pembangunan Sosial dalam hal ini adalah pengembangan dan peningkatan kualitas sumber daya manusia pada sektor perikanan tangkap di wilayah pesisir dan juga berorientasi pada pengembangan sektor perikanan dan kelautan, peningkatan partisipasi masyaralat khususnya lembaga sosial /masyarakat dalam pelestarian kawasan pesisir, penguatan dan penegakan hukum, kelembagan serta program konservasi berbasis masyarakat. 
Selanjutnya agenda pembangunan ekonomi dalam mewujudkan wilayah pesisir Kabupaten Mamuju Tengah yang lebih baik adalah Pengembangan kawasan-kawasan ekonomi khusus serta strategis dan yang berbasiskan pada komoditas unggulan dan untuk mendorong peningkatan kesejahteraan masyarakat, Mempromosikan beberapa wilayah atau desa pesisir yang berpotensi sebagai destinasi wisata dengan cara mengiklankannya di berbagai media baik nasional maupun internasional serta mengadakan event-event tertentu agar dapat menarik minat investor dalam pengembangannya, dan penanganan bantuan modal usaha untuk home industry.

Kemudian pilar ketiga yakni pembangunan lingkungan mempunyai langkah konkret seperti pengelolaan limbah dengan teknik penanganan sanitary landfill, incenerator, serta pengomposan, mensosialisasikan kegiatan pembuangan sampah 4 R (Reduce, Reuse, Recycle and Repair), program rehabilitasi dan pembersihan kawasan sungai dari sampah yang implementasinya sesuai aturan yang berlaku. Rehabilitasi lahan yang ada di sekitar hulu sungai dan pembersihan sampah yang ada di sepanjang sungai, usaha konservasi ekosistem pantai (seperti konservasi terumbu karang dan/atau penanaman bakau /mangrove di wilayah terkena dampak abrasi), pembangunan tanggul-tanggul penahan ombak/pemecah ombak (breakwater) guna meredam gelombang sehingga memberikan kesempatan kepada tanaman bakau untuk tumbuh dan berkembang.

\section{KESIMPULAN}

Terdapat beberapa permasalahan atau yang menjadi penyebab dari kerusakan wilayah pesisir di Kabupaten Mamuju Tengah yaitu pada aspek pencemaran dari aktifitas di daratan dan laut seperti buangan limbah padat dan cair, logam berat perairan, kegiatan pertambakan, kemudian aspek keterbatasan infrastruktur, dampak abrasi dan sedimentasi serta kerusakan ekosistem mangrove.

Sedangkan pada tingkat kerusakan ekosistem mangrove menggunakan regression menunjukkan bahwa variabel penebangan kayu bakau merupakan faktor yang sangat mempengaruhi tingkat kerusakan ekosistem mangrove di kawasan pesisir Kabupaten Mamuju Tengah. Setiap penambahan $1 \%$ kegiatan penebangan kayu bakau akan meningkatkan kerusakan ekosistem mangrove di kawasan pesisir sebesar $0,711 \%$.

Dari hasil analis IPA, diperoleh bahwa yang paling membutuhkan (prioritas) penanganan kawasan pesisir di Kabupaten Mamuju Tengah adalah masalah mangrove terkait dengan eksistensinya dan kerapatannya, kemudian disusul kondisi sempadan pantai, tingkat abrasi yang terjadi pada lokasi penelitian, serta masalah sanitasi/air limbah pada wilayah permukiman masyarakat pesisir. Adapun hasil scoring terkait dengan masalah kerusakan di beberapa kawasan atau pesisir diperoleh bahwa wilayah pesisir untuk kabupaten Mamuju Tengah wilayah yang memerlukan penangan prioritas adalah Kecamatan Pangale.

\section{DAFTAR PUSTAKA}

[BPS] Badan Pusat Statistik Kabupaten Mamuju, 2013. Kabupaten Mamuju Dalam Angka 2013. Badan Pusat Statistik Kabupaten Mamuju. Mamuju.

[BAPPEDA] Badan Perencanaan dan Pembangunan Daerah. 2014. Profil Daerah Kabupaten Mamuju Tengah 2014. Badan Perencanaan dan Pembangunan Daerah Mamuju Tengah. Tobadak.

[BAPPEDA] Badan Perencanaan dan Pembangunan Daerah. 2016. Profil Daerah Kabupaten Mamuju Tengah 2016. Badan Perencanaan dan Pembangunan Daerah Mamuju Tengah. Tobadak. 
Dahuri, Rokhmin; Rais J.; Ginting S.P. dan Sitepu M.J., 2001. Pengelolaan Sumber Daya Wilayah Pesisir dan Lautan Secara Terpadu. Pradnya Paramita. Jakarta.328 p.

[DKP] Dinas Kelautan dan Perikanan, 2016. Rencana Zonasi Wiayah Pesisir dan Pulau-Pulau Kecil (RZWP-3-K) Provinsi Sulawesi Barat . Kelompok Kerja RZWP-3-K Provinsi Sulawesi Barat.

Iriadenta, 2015. Nipah Indikator Degradasi Kawasan Pesisir. Banjarmasin; Unlam Press.

Keputusan Menteri Nomor 201 Tahun 2004 tentang Kriteria Baku dan Pedoman Penentuan Kerusakan Mangrove.

Rahmawaty, 2004. Penanggulangan Kerusakan Ekosistem Terumbu Karang MelaluiPemberdayaan Ekonomi Masyarakat Pesisir dan Kelautan. Tesis tidak dipublikasikan, Program Studi Manajemen Hutan Universitas Sumatera Utara. Medan.

Ridwan, 2005. Skala Pengukuran Variabel-variabel Penelitian. Cetakan ke-3. Penerbit Alfabeta. Bandung.

Soleh, A. Z, 2005. Ilmu Statistik Pendekatan Teoritis dan Aplikatif disertai Contoh Penggunaan SPSS. Penerbit: Rekayasa Sains Bandung. 